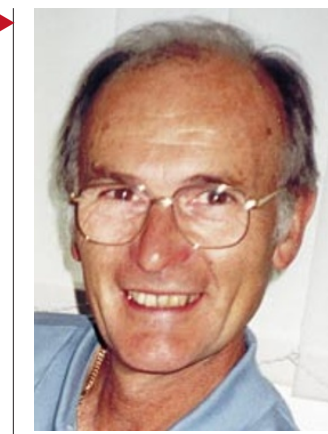

Williamson: champion of structural consortium. may evolve to do this, says John Norvell, head of the US Protein Structure Initiative. But before this can happen many technical and logistical issues need to be resolved.

The Protein Structure Initiative hopes to deal with these issues; it will announce its first round of grants to a handful of pilot centres in the United States next month.

The three existing large programmes in structural genomics are run by the NIGMS, the Institute of Physical and Chemical Research (RIKEN) in Japan, and the Wellcome Trust.

Norvell agrees that a consortium could speed things up. "The participation of industry in the international effort is strongly encouraged," he says. But the NIGMS has not joined the consortium. "It's early in the game for all of us," says Norvell.

The Wellcome Trust's participation in any consortium is conditional on "data being made freely available”, says Morgan. He adds that all the companies in the consortium are against intellectual property being taken on any data that it produces.

\title{
Novartis pins hopes for GM seeds on new marker system
}

Quirin Schiermeier, Munich

The multinational company Novartis Seeds last week launched a campaign to gain worldwide support from the plant-science community for its new marker-gene system, Positech.

The campaign follows the company's recent announcement that it plans to phase out antibiotic-resistance marker genes in its future products, in an attempt to restore public confidence in the safety of genetically modified foodstuffs.

Plant geneticists use marker genes to monitor the transformation of plant cells after a foreign gene has been introduced into a plant along with the marker. The most commonly used markers are antibiotic- or herbicide-resistance genes, which protect the cells against an agent introduced to kill those that have not taken up the desired DNA.

But concerns have been triggered about the potential threat to public health. There are fears that antibiotic resistance genes could 'jump' from transgenic plants to microorganisms such as gut bacteria, increasing antibiotic resistance in humans.

The Positech marker system uses transformed plant cells that contain the gene encoding the enzyme phosphomannose isomerase (PMI). In the selection process, only the cells that take on the PMI trait can survive in a culture in which they are fed only mannose, a simple sugar. Novartis says the system has been tested successfully with transgenic maize and wheat.

"Positech is well along on the development path," Wally Beversdorf, head of research and development at Novartis Seeds, told last week's International Crop Sciences Congress in Hamburg. "We will have regulatory packages containing PMI probably within 12 to 18 months."

Basic researchers, who can use 'Positech' without royalties, have welcomed the launch. "The availability of less controversial marker genes would certainly improve the acceptance of our research, and cool down the public debate," says Uwe Sonnewald, head of molecular cell biology at the Institute for Plant Genetics and Crop Plant Research in Gatersleben, Germany.

But environmental groups say that phasing out antibiotic-resistance marker genes would only be a small improvement. Greenpeace has called Novartis' campaign "mere propaganda" aimed at easing consumer concerns about genetically modified foods. "Other important issues, such as the ecological impact of gene transfer into the environment, are ignored," says a spokesman.

\section{Cambridge seeks $£ 1.6$ million to buy Newton’s papers}

\section{Natasha Loder, London}

An unrivalled archive of Sir Isaac Newton's scientific writings could be created if the University of Cambridge succeeds in its bid to buy a collection of documents and letters owned by the ninth Earl of Macclesfield.

Valued at $\mathfrak{E} 6.37$ million ( $\$ 9.4$ million), the collection is considered to be one of the most important in private hands at present. The university wants to unite the papers with its existing collection of related papers, which already forms the world's most complete collection of Newton material.

The UK Heritage Lottery Fund, which offers money from Britain's National Lottery, has already agreed to put $\mathfrak{E} 4.79$ million towards the purchase to safeguard the heritage of objects important to "the formation of the character and identity of the United Kingdom".

The university is now seeking the remaining funds from private benefactors. But Patrick Zutshi, keeper of manuscripts at the university library, says that even if it fails to raise the money, the library would be prepared to go into debt to get the papers.

Newton, who lived from 1642 to 1727 , spent nearly 40 years at the University of Cambridge, where he was appointed Lucasian professor of mathematics in $\mathbf{1 6 6 9 .}$ It was during this time that he laid much of the foundations for modern mathematics, astronomy and physics.

The auction house Sotheby's is negotiating the sale of the papers on behalf of the Earl of Macclesfield. Although he is likely to have got a higher price through an auction, the Earl is keen for the collection to go to the university.

Other leading mathematicians of the day whose papers appear in the collection include Christiaan Huygens, Pierre de Fermat, Robert Boyle, John Flamsteed and Isaac Barrow. The collection also contains an unpublished 200-page manuscript Astrologia Rationis Argumentis Solidis Explorata by Nicolas Mercator, the astronomer and mathematician who invented the pendulum marine chronometer.

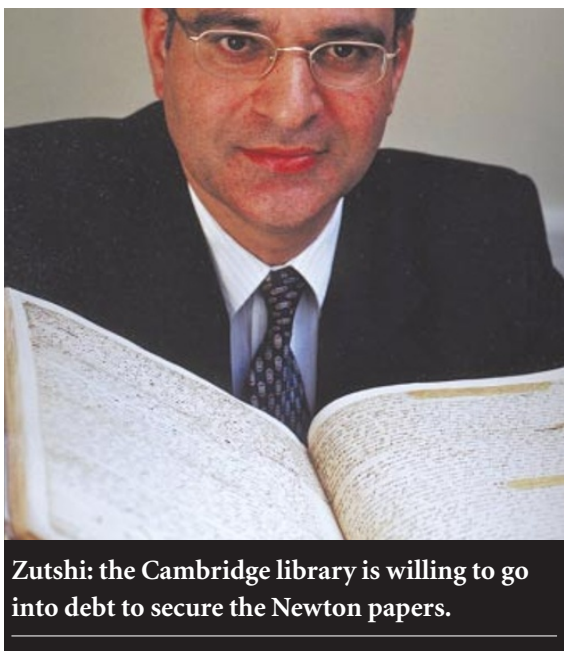

Peter Lipton, head of history and philosophy of science at the university, says if the purchase bid succeeds, conservation work will be carried out on the papers before they are put on public display.

http://www.lib.cam.ac.uk/

http://www.sothebys.com/ 